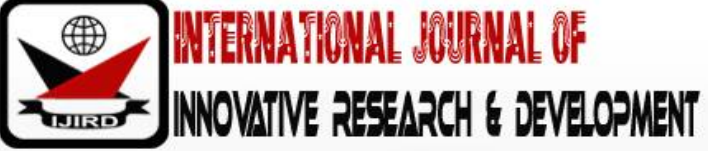

ISSN 2278 - 0211 (Online)

\section{Approaches to Effective Teaching of Mathematics in Secondary Schools}

\author{
Dr. P.C. Igbojinwaekwu \\ Associate Professor, Department of Science Education, \\ Niger Delta University, Wilberforce Island, Nigeria
}

\section{Abstract:}

This paper focused on some approaches to effective teaching of mathematics in schools in order to have a sustainable high academic achievement or performance of our, students in secondary schools. These approaches were prior knowledge of topic to be taught, behavioural objectives and study questions, creating, good conducive learning environment, improvisation and proper use of instructional materials and application of appropriate teaching methods and strategies.

Keywords: Teacher's preparation for lesson; Mathematics in Nigeria Secondary Schools, Prior knowledge of behavioural objectives and study questions; Improvisation and proper use of instructional materials, Advance organizer, Conducive learning environment, Collaborative and cooperative learning ; Mathematics laboratory; Assignments.

\section{Introduction}

Any time the teacher wants to teach a concept, his troubles are usually

- What to teach,

- Who is to be taught and

- How is the concept going to be delivered?

These questions are usually taken very serious in teaching process, because the basic aim of teaching is proper understanding of the concept to be taught. Therefore, this lecture has to clarify what these questions are all about.

What is to be taught, the content of the concept the teacher is to teach? The teacher must be a mastery of his subject. This attribute is very important, because the students will have confidence in you. Remember that you c3nnot give what you do not know. The pre-requisite of the content to be taught must be known by the teacher.

Who is to be taught? the students; the average age of the students should be ascertain before teaching This is very important in order to know the appropriate words to use during lesson delivery. Find out the level of preparedness of the students using the pre-requisite. If there is still need to reinforce it, please do. Do not assume that they have the required background. This is where many teachers fail in their duties! How is the concept going to be taught? This is basically the methods/ strategies of teaching. Firstly, list the behavioural objectives to be achieved. These are what the students should know by the end of the lesson. Secondly, dismantle the context into small phases that can be easily achievable at a time base on the stated behavioural objectives. Teach the students, using appropriate strategies and instructional materials to make learning easily assessable.

The Place of Mathematics in Nigerian School and Society. It is a common knowledge that any school, be it at the primary or secondary or tertiary level, that fails to provide Mathematics Education is viewed as being unserious. This is because of the key position Mathematics occupies in the Nigerian Educational System and its application in developmental process. In this vein, Akuezuilo and Chinweoke (2009), stated that Mathematics is the bedrock of all Science Subjects and is therefore, needed for scientific and technological advancement of any nation. Maduabum and Odili (2006), described Mathematics as the Science of quantity and space which occupies a key position in the Nigerian Educational System reflecting accurately the vital role the subject plays in contemporary society. According to Osafehinti (1990) and Aminu (1995), any society which aspires to be scientifically and technologically developed must have adequate level of Mathematics Education since Mathematics has ingredients for the effective articulation of the abstract elements of science that gives impetus to the development of technologies. Rogers (1986), explained that Mathematics has become the central intellectual discipline of the technological society and that as the society develops so will its quantitative aspects assume greater influence and dominance over its qualitative features. Eguavon (2002), described mathematics a.s the pivot of all civilization and technological development. Supporting. Eguavon, Imoko and Agwagah (2006), opined that Mathematics is a key factor in the development of any nation. Mathematical concepts and symbols are used in expressing the physical laws of nature (Tsue and Anyor, 2006). Therefore, Mathematical concepts and methods provide scientists with insight, into and about natural phenomenon. Ikeobi (1994) and Njoku (1997), opined that chemical Kinetics, chemical equilibrium, stoichiometry, mole concept, solubility, electrolysis, redox reactions and ionic equations are areas in chemistry that 
require a good knowledge of mathematical concepts. Jegede (1979), identified ratio, charts, proportions, measurement and statistics as the mathematical concepts needed in biology. Egbugara (1980) indicated that algebra, trigonometry, graphs, calculus and differential equations are the mathematical concepts required in physics and engineering science. Regrettably, despite the importance of mathematics as a key subject in realizing any nations scientific and technological aspirations, there is ample evidence of continued low interest in the subject by Nigerian students (Odili. 1992).

Also, reporting to the National Council on Education (NCE) on students' performance in the May/June SSCE, the West African Examination council (WAEC, 2012) lamented the low achievement and Interest in mathematics by Nigerian candidates.

Many reasons have been advanced for the dismal state of mathematics. While some researchers (Ali, 1989; Harbor- Peters, 1992) viewed teachers' incompetence as a contributing factor, other findings (Adeniyi. 1988; Alio and Harbor-Peters, 1997) attributed the low interest in mathematics to teachers' non utilization of appropriate teaching techniques. Many teachers in schools use only techniques they know even if such techniques are not relevant to the concept under discussion (Akinsola and Popoola, 2004). Opara (1995) advised that teachers should evolve strategies that involve learners active participation. Such strategies will generate interest in the students.

Realizing the views of the aforementioned researchers on the importance of mathematics in national development and its position in the school system, the Federal Republic of Nigeria (FRN) (2004) is continuously emphasizing the importance of Mathematics in national development by making the subject compulsory for both pupils and students in Primary and Secondary Schools. Supporting (FRN), Maduabum and Odili (2006), asserted that for a nation such as ours, aspiring for scientific and technological take-off, the need to pay due attention to our students academic performance in mathematics cannot be over emphasized.

Improvisation and Proper Use of Instructional Materials:

Akuezuilo and Chinwleoke (2009), agreed that for students to have high academic achievement in Mathematics, teachers should be able to skillfully apply relevant instructional materials, in order, to drastically reduce the abstract and difficulty attributes of Mathematics. Also, Gbodi and Laleye (2006) and Alio,Ude and Okoye (2009), pointed out that the application of relevant instructional materials in teaching.

Mathematics, at the right time, gives better result than mere talking and writing. Abimbadc (1997) stated that sonic materials are needed and essential for the purpose of bringing about. effective teaching and learning which are called instructional materials or instructional media. According to Gbodi and Laleye (2006), instructional materials are possible channels through which information are conveyed from sender (the teacher) to the receiver (the student). Fademiro (2000), perceived instructional materials as the materials, equipment and techniques that can be used to communicate with the listeners (students), as well as, create opportunity for independent learning. Ugbede in Obara and Okoh (2005), opined that instructional materials are tools for communication; they refer to all things that can be seen, heard, read and manipulated with the objectives of enhancing the teaching-learning process. Okafor (2003), defined instructional materials as aids to effective teaching and which aid effectiveness in classroom by evoking in the students the mental image as in the teacher, thereby making words less ambiguous. Obara and Okoh (2005), asserted that instructional materials are all the things the teacher utilizes to interactively enhance, motivate and facilitate teaching and learning in an attempt at ensuring the achievement of a set of objectives. According to Abimbade (1997), instructional materials are broad ranges of resources, which can be used to facilitate effective and efficient communication One of such instructional materials is the audiovisual material.

Audio-visual material is a type of instructional material that aids in making ideas or concepts clearer in instructional programmes, but should not be regarded as a substitute for good teaching (Moronkola, 2012). Fademiro (2000) posited that audio-visual materials are devices that have both audio and visual appeal; they require the use of the eyes and ears (sight and hearing). The videotaped instructional material is an example of audio-visual material. Gbodi and Laleye t2006), posited that videotaped recorder is an audio-visual material useful for programming instruction on topics that a.re abstract and difficult to explain verbally.

Video and television constitute very important audiovisual material and could be used for effective teaching and learning of Mathematics in the classroom. According to Callahan and Clark (1977), students tend to enjoy viewing and they understand messages from video and television much faster. Gbodi (1998) reiterated that knowledge enters the human brain mainly through two major senses, sight and hearing; sight covers between 75-90\% and hearing 10-15\%. Supporting Gbodi (1998), Gbodi and Laleye (2006), stated that the effectiveness through sight and hearing is that students can remember $30 \%$ of what they hear and $50 \%$ of what they hear and see simultaneously. Nneji (2000), detected that videotaped instruction has the potential of enhancing quality learning; it can be used to arouse interest, modify attitude, clarify concepts, stimulate contents, demonstrate and concretize knowledge that could otherwise only be talked about in abstract terms.

It is an unarguable fact that teaching-learning process goes on smoothly with the aid of instructional materials. Therefore, one can safely say that teaching-learning process cannot go on if at least one instructional material is not available. There are situations when instructional materials are grossly inadequate. This is supported by Aghenta (2001), who asserted that school buildings are inadequate, old and dilapidated; classrooms and laboratories are inadequate and ill equipped; chemicals, tools, books, teaching aids and other useful equipment are terribly inadequate. According to Aghenta (1992), those materials are the ingredients for promoting quality education, and in Nigeria, they are hardly available to the teachers. In this situation, the teachers are expected to improvise or be deeply involved in improvisation. To improvise means to provide or make or do something quickly in terms of need, using whatever means to make it available (Hornby and Cowie, 1985). Akanbi (1989), agreed that improvisation refers to a creative conceptualization, design and production of instructional materials which are substitutes to original types which might be too expensive to purchase or whose 
constituent elements or Structural makeup might be rare to find. According to Animalu (1977), improvisation means technology transfer or research in areas which may not appear original scientifically in the world context, but which include important technical steps that must be mastered if the nation is to join the industrial age. These include elaboration of' existing technology, dismantling and copying model products, transfer of technology, adaptation of products, etc. Balogun (1982) saw improvisation in science as an act of using alternative material resources to facilitate instruction whenever there is lack or shortage of some specified first hand aids. Akusoba (1985), defined improvisation as the choice of the best instructional materials which enables the teacher to achieve carefully specified educational objectives. He added that improvisation should not be seen as the second best, but an alternative best. Following the aforementioned definitions of improvisation, lgbojinwaekwu (2009), concluded that it is, therefore, clear that improvisation seeks to solve problems of non-availability of certain elements or materials required or the problem of insufficient number. According to him, problem solving is the main essence of improvisation and constitutes the core quality that made many of the teachers in the colonial era outstanding. Obanya (1989) reminded us that the training of teachers should emphasize the production of resourceful teachers who think about learning problems and constantly attempt to solve them. To buttress the importance/ advantages of improvisation, Akanbi (1989), stated that, it

- Encourages the use of local materials,

- Promotes ingenuity, creativity and acquisition of a problem solving skill and

- Enables the teacher and the learner to jointly and individually explore different strategies for overcoming problems in the class.

Basic Approaches To Effective Teaching of Mathematics These include:

- Prior knowledge of the topic to be taught, it behavioral objectives and study questions.

- Creating of good conducive learning environment,

- Use of advance organizers,

- Cooperative / collaborative learning

- Use of mathematics laboratory

- Use of familiar games and

- Giving adequate exercises to students in order to properly develop their cognitive capacities.

It is a common knowledge that teacher's lesson note has its behavioural objectives. That is, those things the students should know by the end of the lesson. Also, modern text books list the behavioural objectives at the beginning of every chapter. Hartley and Davis (1979) pointed out that when students are exposed to the behavioural objectives of a concept before the commencement of a lesson on the same concept, it provides the students with a clear goal that can be used to organize learning activities, permits students to study more effectively and reduces the time wasted on irrelevances as well as provides a bench mark against which they can objectively evaluate their own progress. The exposure of students to the behavioural objectives of a concept before the commencement of a lesson is known as prior knowledge of behavioural objectives. when a teacher states the questions whose answers are to be known by the students before commencing his/ her lessons, the students are more focused than when a teacher just starts teaching any concept. Also, Hartly and Davis (1979) pointed out that students with prior knowledge of study questions in the same concept to be taught by the teacher have a clear goal that can be used to organize learning activities, are permitted to study more effectively by reducing the time wasted on irrelevances as well as are provided with a bench work against which they can objectively evaluate their own progress. Mkpa (1985) asserted that the use of questions in instruction does not simply provide students with answering skills, but in addition, indicates to students what they need to do and how they are do it, giving them greater control over their own learning process and encourages students' motivation and learning.

Advance organizers are described as what the teacher teaches to the child whom the child will link up to the new concept/ topic at hand. Chinweoke (2008) declared that learning can be viewed as the extent to which the learner is able to integrate old learning to accommodate new learning which fixed properly into the aim of using advance organizer with an instructional approach. For example, using the students' knowledge of uncountable nouns (in English language class) as an advance organizer in teaching undefined fractions in mathematics; teacher can ask the students to give examples of uncountable nouns (quantities of water, sand, garri (Nigerian food derived from Cassava tuber), rice etc); ask them again why these quantities are called uncountable nouns (because the real values of the quantity cannot be found). Tell them that these quantities are also said to be undefined. Remember that these quantities are said to be undefined when they are not measurable, that is, the actual value cannot be determined. But whenever they are measured say in cups, tins, bottles etc they are no longer undefined but defined e.g. a cup of water, a bag of sand, a bag of garri etc. In Mathematics, any fraction that has its denominator as zero (0) is said to be undefined fraction. Example, 2/ 0,100/ 0,13/0, etc, which means that the actual value of the fraction is uncountable or indefinite, unquantifiable or undefined. When this is properly illustrated, anytime the students come across the word undefined' fraction they will quickly link it up to something that is uncountable or indefinite or unquantifiable. Advance organizers are usually an introductory lesson which can be in form of lyrics, short story telling, short discussion, examples, questions, etc that can be linked to the new lesson, Cooperative learning is a teaching approach in which students are divided into small groups, usually five students per group. This grouping has to be mixing ability levels, sex, and age. Each group has to be gain different activities to perform to help concretize their comprehension of the lesson. In each group, a leader is appointed to direct others on what to do in order to achieve the particular objective. Example, in a group of five students, you can give out a number of problems for them to solve. In each problem say equation one person will be solving and asking question to the rest of the students in the group while the rest will be listening, watching and answering the questions.

Collaborative learning on the other hand is a team work where students also work in groups to achieve a particular objective. Here various aspect of the work/ project are shared among them in the group, each working to achieve 
a goal, anybody in a group who fails to do his/ her own part well will affect the successful completion of the protect.! For example, in building a model of shapes; work can be distributed in such a way that a particular student may collect clay, other water, or hoard, other mix up the materials, while the other will do the moulding that is putting the whole things in the required shape.

Mathematics laboratory is a place where mathematical principles, ideas, facts and concepts are concretized and demonstrated to students. It is an experimental room for teachers and students to teach and learn mathematics. Some people think that it is only science and technology that require

Laboratory, mathematics, also, needs laboratory where materials and instruments for teaching mathematics are built and kept. For example, solid shapes, abacus, construction instruments, weighing and measuring instruments are kept in the laboratory to be used when the need arises. So, mathematics teachers should make sure that they make effective use of' their mathematics laboratory where available to help them concretize their lessons. Example, in teaching students about properties of plane figures and shapes, this can he carried out practically in the laboratory using concrete materials like papers. You may cut out the papers into shapes and show the students the features of those shapes.

Use of mathematical games like ludo games, throwing dice, card games, etc concretize some abstract concepts in mathematics. For example, in teaching probabilities, the teacher can make use of these devices to help effective delivery of his lesson. This will help the students to learn, understand and retain the various mathematical concepts to which the games are related.

\section{Conclusion}

Mathematics is expected to equip the learners (students) with relevant knowledge; skills and competencies that can enable them function effectively and become self-reliant individual. So for these to be achieved, science and mathematics teachers should endeavour to teach this subject using the approaches discussed above in addition to the ones they already have, in order, to effectively produce entrepreneurial students. Entrepreneurial experience in mathematics will enthuse students' individual skills, talents, knowledge, competencies, hence making them to be self-reliant and selfemployed which positively will help to build our nation into a giant nation, and a place full of opportunities.

\section{References}

i. Abimbade, A. (1997). Principles and Practice of Educational Technology. ibadan: International Publishers.

ii. Adeniyi, N.E. (1988). Mathematics in schools. Abacus. 18 (1), 89-106.

iii. Aghenta, J.A. (1992).Why there are not enough science applicants for university admission in Nigeria. Journal of Science Teachers Association of Nigeria. 20(2), 90-99.

iv. Aghenta, J.A. (2001). A turning point in education and development in Nigeria. The inaugural lecture series 58 of University of Benin, Bertin City.

v. Akanbi, A. (1989). Improvisation in Science Teaching. Journal of Technology and Science Education. 1(1), 9-21.

vi. Akinsola, M.Kand opoola, A.A. (2004). A comparative study of the effectiveness of two strategies of solving mathematics problems on the academic achievement of secondary school student, Abacus: Journal of the Mathematical Association of Nigeria (JMAN), 29 (1).

vii. Akuezuilo, E.O. and Chinweoke, F.U. (2009). Effectiveness of prior knowledge of Behavioural Objectives and study Question of female Students Mathematics Achievement. Unizik Journal of STM Education: 1,(1) 1-7

viii. Akusoba, EU. (1985). Improvisation based on local resources for the Teaching of Basic Science concepts. Journal of Science Education, College of Education, Nsugbe. 1(1).

ix. Ali, A (1989). Content competence in Mathematics attained by grade II teachers for teaching primary mathematics Journal of educational studies. Institute of education, university of J08. Nigeria. 1(2), 28-43.

x. Alio, B.C and Harborpeters V.F (1997). The effect of polycis problem solving technique on secondary school sudcnts, achievement in mathematics. ABACUS: JMAN, 25, (1)-26-38.

xi. Alio, B.C, Ude, D and Okoye, K.R.E. (2009). Effects of the use of Geoboard Teaching on Primary School Pupils Academic Achievement in Mathematics in Enugu south Local Government Area of Enugu state. Unizik Journal of STM1.(1).

xii. Arninu, J. (1995). Quality arid Stress in Nigeria Education. University of Benin, Benin City.

xiii. Animalu, A.O. B. (1977). The Priority for Science and Technology Education in Nigeria: A keynote address at the opening of the Nigerian Institute of Physics (NIP)/ Federal Ministry of Education Workshop for Secondary School Physics Teachers held at the University of Nigeria, Nsukka.

xiv. 1 A. (1982). Improvisation of School Science Teaching Equipment. Journal of Science Teachers Association of Nigeria (JSTAN). 20(2).

xv. Callahan, J and Clark, L. (1977). Teaching in the Secondary Schools: Planning for Competence. New York: Macmillan.

xvi. Chinweoke, F.U. (2008). Use of advance organizers as an instructional strategy for teaching of undefined fractions. Journal of Science teachers association of Niqeria (STAN). 11(1).

xvii. Egbugara, U.O (1989). An Introduction of Aspects of Students Problem Solving Difficulties in Ordinary Level Physics. uournal of Science Teachers Association of Nigeria (JSTAIV). 26(1), 57-68.

xviii. Eguavon, O.J. (2002). Mathematics the Heartbeat of Information Technology: Implication for secondary Education. Abacus: JMAN. 27(1), 10-12. 
xix. Fademiro, J. (2000). Use of Instructional Media in Teaching and Learning of Environmental Sciences in the Universities of Technology. Nigerian Association for Educational Media and Technology: 21st Century Convention Proceedings. 156-159.

xx. F.G.N. (2013). National policy on Education. Lagos: NERDC Press.

xxi. Gbodi, E.B. (1998). The Effect of Visual Perception and Gender Differences on Nigerian Senior Secondary School

xxii. Students Achievement in Selected Physical Geography Concepts. African Journal of Information Technology (AJ1T). 1.(1), 4 7-50.

xxiii. Gbodi, E.B. and Laleye, A.M. (2006). Effect of Videotaped Instruction on Learning of Integrated Science. Journal of Research in Curriculum and Teaching. 1(1), 10-19.

xxiv. Harborpeters V.F. (1992). Aspects of further mathematics that present difficulties to graduating senior secondary students ABACUS: JMAN 22.(1), 74-78.

xxv. Hartley, J. and Davis, LK. (1976). Pre-instructional strategies: the role of pre-test, behavioral objectives, Overview and advance organizers. Review of educational research 46(2).

xxvi. Homey, A,S. and Cowie, A.. (1985). Advanced Learners Dictionary of Current English. London, Oxford press.

xxvii. lgbojinwaekwu, P.C. (2009). Hints and Suggestions on improvisation of instructional materials at the Basic Educational Level. A paper presented at a workshop on the use of the new 9-years curriculum for JSSI teachers in Delta. State, organized by Delta State Universal Basic Education Board from 24th - 25th June, held at Our Lady's Girls' High School, Effurun, Warn, Nigeria.

xxviii. Ikeobi, I. (1994), Identification and Teaching Different Concepts in Chemistry.JSTAN.11(2), 3-5

xxix. Imoko, 8.1. and Agwagah, U.N.V. (2006). Improving Students Interest in Mathematics through the Concept Mapping Technique. A Focus on Gender. Journal of Research in Curriculum and Teaching. 1(1), 30-38

xxx. Jegede, O.J. (1989). Mathematical Requirement of West African School Biology (1970-1985). JSTAN. 26(1), 12-23.

xxxi. Maduabum, M.A. and Odili, G.A. (2006). Analysis of Students' Performance in General Mathematics at the Senior School Certificate Level in Nigeria from 1991-2002. Journal of Research in Curriculum and Teaching. 1(1), 64-68.

xxxii. Mkpa, M.A. (1985). A study of the effect of two types of instructional review questions on the learning and remembering of written education content. Nigeria educational forum.

xxxiii. Moronkola, O.A. (2012). School Health Programme. Ibadan: Royal people Nigeria Ltd

xxxiv. Njoku, Z.C. (1997). Effect of Practical Work Under Different Sex Grouping on Students Skill Acquisition and Interest in Chemistry Practical Activities. Unpublished PhD Thesis, University of Nigeria, Nsukka.

xxxv. Nneji, L.(2000). Video Film as a Science Teaching Tool. Journal of Science Teachers Association of Nigeria. 1(1), $143-45$.

xxxvi. Obanya, P. A.. (1989). Towards a Return to Resourcefulness in Teaching. lnOgurant,A.(Ed). Problems arid Prospects of Education Technology in Nigeria. Ibadan, Heinemann. 16-21.

xxxvii. Obara, J.K and Okoh, C. (2005). Instructional Media Production: The Need for Provisional and Innovation. African Journal of Education and Development Sttdies (AJEDS). 2 (182), 129-36.

xxxviii. Odili, G.A (1992). The training of NCE mathematics teachers: a focus on instructional materials. ABACUS: JMAN. 22(1), 98-105

xxxix. Okafor, A.M. (2003). Application of Instructional Materials for Effective English Language Teaching and Leaxning: Implication for Universal Basic Education (UBE). In Chibuogu, V.Nand Chibueze, A.S. (Ed). Science and Technology for Sustainable UBE in Nigeria.

xl. Osafehinti, N. (1990). Effects of Video and Audio Rolling Graph among Students in Achievement and Retention in the Understanding of Schistosomiasis. Unpublished Ph.D Thesis, University of Nigeria Nsukka.

xli. Osafehinti, J.0. (1990). The Universality of Mathematics. Journal of Mathematics Association of Nigeria (JMAN). 20(1), 48-56.

xlii. Rogers, M. (1986). Science, Technology and Society. Chicago:University of Chicago Press.

xliii. Tsue, E. A and Anyor, J.W. (2006) Relationship between Students' Achievement in Secondary School Mathematics and Science Subjects. Journal of Research in Curriculum and Teaching. 1(1), 48-54.

xliv. WAEC (2012), Chief Examiner's Report. Lagos: West African Examinations council. 